\title{
Note
}

\section{The effect of oestrus synchronization and mating season on the productivity of Pelibuey ewes}

\author{
I.L. FUENTES, Y. COGNIE * et T. LIMA \\ Estacion Experimental Ovina, Centro de Investigacion para el Mejoramiento Animal, \\ Carretera Central, $\mathrm{km} 21 \mathrm{l} / 2$, Cotorro, C. de la Habana, Cuba \\ * I.N.R.A. Station de Phvsiologie de la Reproduction \\ Centre de Recherches de Tours, F 37380 Nouzilly
}

\begin{abstract}
Summary
One hundred eighty Pelibuey ewes were placed in an experimental programme designed to obtain three lambings in two years. The animals were grazing and received a concentrate supplement. They were divided into three identical groups : a) Treated with vaginal sponges (FGA and PMSG), b) Treated with subcutaneous implants (Norgestomet and PMSG) and c) A control group. The ewes were treated in July 1979, March and October 1980. The mating period for the control group was 35 days. There was significant differences between synchronization methods and seasons on fertility $(83.7,92.2,84.9,92.1,78.5$ and 88.0) with treatments $\mathrm{a}, \mathrm{b}$ and $\mathrm{c}$ and in July, March and October, respectively. Also significant effects were found for the synchronization methods and seasons of the year on prolificacy $(166,150,148,169,149$ and 147) with treatments $a, b$ and $c$ and in July, March and October, respectively. No significant differences were encountered in oestrus occurrence for the synchronization methods or seasons of the year $(100$. 100, 98.2, 98.3, 99.4 and 100 for a, $\mathrm{b}, \mathrm{c}$ and in July, March and October, respectively). Production of alive born lambs per ewe for two years was : $4.15,4.16$ and 3.78 for treatments $a, b$ and $c$, respectively. The results of this study indicate the possibility of employing this system in Pelibuey ewes without oestrus synchronization.
\end{abstract} fertility.

Key words : hair sheep, oestrus synchronization, mating season, accelerated lambing,

\section{Introduction}

Hair sheep population (10 p. 100 of the world sheep population) is well adapted to tropical environment and is found on many Caribbean islands and in central and south American countries. Hair sheep were introduced to the West Indies in the seventeenth century A.D., probably from the central portion of West Africa (MAson, 1980). 
In a recent and well documented book, FitzhUGH \& BRADFord (1983) provided a general description of current production systems of hair sheep living in tropical area, in Western Africa and America and assumed that it was " a genetic resource with considerable potential for meat production in developing countries».

Observations carried out on our sheep at the experimental station of Cotorro (La Habana) confirmed that like in Mexico (Valencia et al., 1975) Pelibuey ewes exhibit oestrus throughout the year in Cuba. However, it occurs more frequently between July and October.

It therefore seemed to be interesting to increase the annual output per ewe by developing intensive breeding programmes that would take advantage of these facts (THIMONIER \& COGNIÉ, 1977). On this basis, we studied the reproductive ability of Pelibuey ewes using a system based on three lambings every two years, with or without oestrus synchronization with progestagen treatments and associated or not with artificial insemination.

\section{A. Experimental methodology}

One hundred eighty non lactating Pelibuey ewes that had lambed two or three times previously, were divided into three experimental groups of 60 animals. Two groups were treated with vaginal sponges impregnated with $30 \mathrm{mg}$ of fluorogestone acetate (FGA ; $9 \alpha$-fluoro-11 $\beta$-hydroxy-17 $\alpha$ acetoxy-pregn-4-ene-3.20 dione), another group with subcutaneous implants containing $1.3 \mathrm{mg}$ Norgestomet (17 $\alpha$-acetoxy$11 \beta$-methyl-19-nor-pregn-4-ene, 3.20 dione) and the last one was a control group. The experiment was carried out in July $1979(n=180)$ and March $(n=168)$ and October $1980(n=167)$ with identical groups of ewes as regards mean liveweight and age and after weaning of the lambs two months after birth.

The ewes grazed low quality pastures during daylight hours and at night they were confined. They received a concentrate supplement daily $(150 \mathrm{~g})$ and hay ad libitum.

The sponges and implants were used for 10 days (COGNiÉ \& MaulÉon, 1983) and after their removal 500 IU PMSG were injected intramuscularly. Oestrus was controlled with teaser rams 24 and $48 \mathrm{~h}$ after the sponges and implants were removed, and in the morning and afternoon for 35 days in the control group.

The treated animals were mated $54 \mathrm{~h}$ after the sponges or implants were removed. Each group was divided into two, one group being inseminated artificially and the other naturally. The control group was naturally mated. As suggested by Colas (1979), fresh semen $\left(15^{\circ} \mathrm{C}\right)$ was employed for AI. The sperm concentration was 500 millions per dose in a volume of $0.2 \mathrm{ml}$. For both $\mathrm{AI}$ and direct mating, each ewe received only one service per oestrus. Those ewes returning to oestrus were mated once more by the same method. Each ewe received a maximum of two services in each mating period.

* FGA sponges and Norgestomet implants were provided by Intervet S.A., 43, avenue Joxé, 49000 Angers (France). 
Annual productivity was defined as the number of lambs weaned (75 days) per treated ewe.

\section{Results and discussion}

The percentage of ewes in oestrus was high in all groups, in the treated females during the first $48 \mathrm{~h}$, and in the control group over 35 days, in all three mating periods (table 1).

\section{TABLE 1}

Effects of synchronization treatment and season on the occurrence of oestrus, fertility (first plus second oestrus) and prolificacy of ewes.

Influence du mode de traitement et de la période de lutte sur l'apparition de l'oestrus, le taux de fertilité $\left(1^{e r}+2^{e}\right.$ cycle) et le taux de prolificité des brebis.

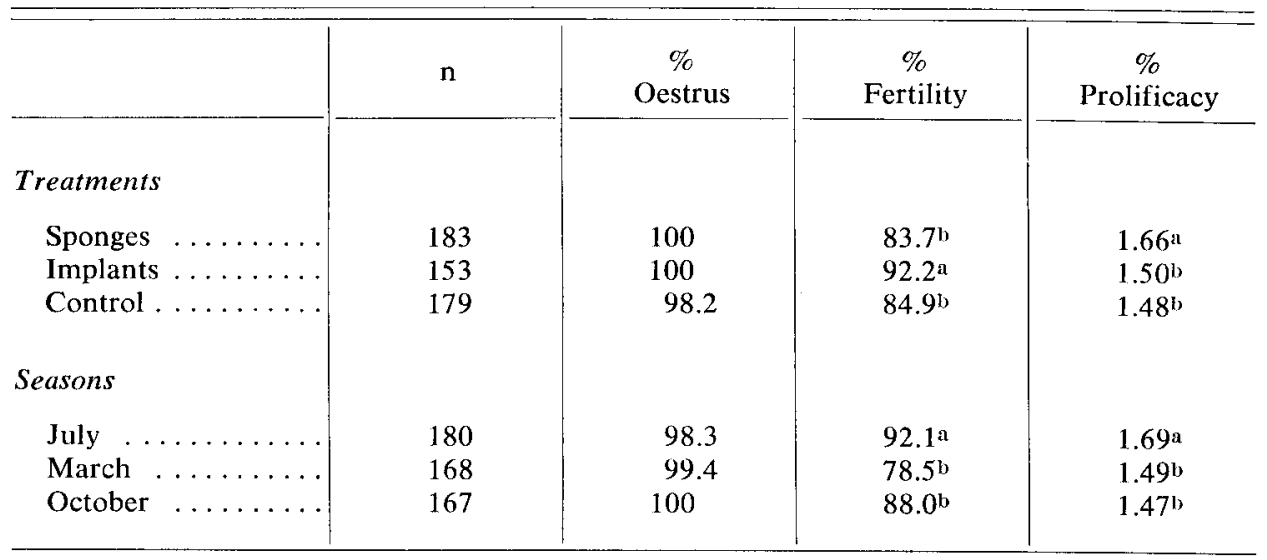

a b Means without letters in common differ at $\mathbf{P}<0.01$.

However, the treatments employed for oestrus synchronization and the periods of the year in which they were used had marked effects on fertility and prolificacy. The best treatments were the implant for fertility and the sponges for prolificacy. On the other hand, the most favourable month was July $(P<0.01)$. The other two months did not differ for fertility and prolificacy percentages.

Percentage fertility for first service varied according to the insemination system. There was an increase of 12.4 p. 100 in favour of natural mating compared to $\mathrm{Al}$ (table 2). 
TABLE 2

The effect of $A I$, mating and season

on fertility and prolificacy percentages at induced oestrus.

Influence du mode de fécondation et de l'époque de lutte sur les taux de fertilité et de prolificité obtenus à l'oestrus induit.

\begin{tabular}{|c|c|c|c|c|}
\hline \multirow{2}{*}{ Measurements } & \multicolumn{2}{|c|}{ Fertility } & \multicolumn{2}{|c|}{ Prolificacy } \\
\hline & $\mathrm{Nb}$ of ewes & Percentage & $\mathrm{Nb}$ of ewes & Percentage \\
\hline \multicolumn{5}{|l|}{ Insemination } \\
\hline Sponges & 103 & 58.3 & 60 & 1.75 \\
\hline Implants & 75 & 65.3 & 49 & 1.65 \\
\hline Total & 178 & $61.2^{\mathrm{b}}$ & 109 & 1.66 \\
\hline \multicolumn{5}{|l|}{ Mating } \\
\hline Sponges & 81 & 69.1 & 56 & 1.62 \\
\hline Implants $\ldots \ldots$ & 75 & 78.7 & 59 & 1.59 \\
\hline Total $\ldots \ldots$ & 156 & $73.7^{\mathrm{a}}$ & 115 & 1.61 \\
\hline \multicolumn{5}{|l|}{ Seasons } \\
\hline July . & 71 & $76.0^{\circ}$ & 54 & 1.72 \\
\hline March & 65 & $50.8^{d}$ & 33 & 1.75 \\
\hline October & 48 & $60.4^{\text {de }}$ & 29 & 1.55 \\
\hline
\end{tabular}

a b Means without letters in common differ at $\mathrm{P}<0.05$.

The treatments did not affect the annual productivity of ewes and it is noteworthy that those females which were not synchronized (control) produced a high number of lambs, similar to that produced when sponges or implants were used (table 3).

TABLE 3

Productivity of ewes in each treatment and season of the year.

Productivité obtenue par brebis en fonction du mode de traitement et de l'époque de lutte.

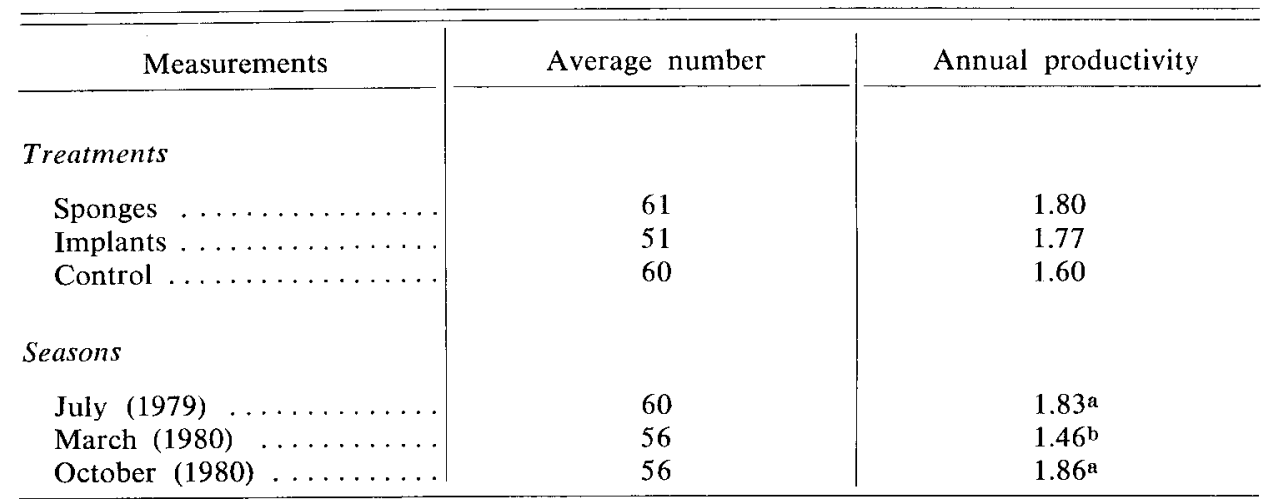

a b Means without letters in common differ at $\mathrm{P}<0.05$. 
This indicates that this breed would maintain high productive indices throughout the year. The best periods for mating were July and October when an average of 1.83 and 1.86 weaned lambs per ewe respectively were obtained. This differs significantly from March $(P<0.01)$. Nevertheless, the number of lambs born alive per ewe during the three mating periods was : $4.15,4.16$ and 3.78 for the sponges, implants and control treatments respectively.

\section{Conclusions}

There are several outstanding practical aspects of this work :

- The major part of the ewes exhibited oestrus when they were synchronized and also 98.2 p. 100 of the non-treated females were in heat over 35 days.

- The season and the oestrus synchronization methods affected fertility percentage. The best results were found when implants were used and July was the most favourable mating period.

- Prolificacy was high when sponges were used for oestrus synchronization and the season with the best results was July. However, annual productivity was not affected by the oestrus synchronization treatments, but by the mating season, March being the least favourable.

- These data confirm previous observations on Pelibuey ewes. This breed is characterized by exhibiting oestrus throughout the year indicating that it is feasible to develop reproductive programmes (three lambings in two years) without oestrus synchronization.

\section{Résumé \\ Influence de la synchronisation des chaleurs et de la période de lutte sur la productivité de brebis Pelibuey}

L'étude de la productivité d'un troupeau de 180 brebis de race Pelibuey a été réalisée dans un système de 3 agnelages en deux ans. La faible qualité des pâtures a nécessité un apport journalier de foin et d'aliment concentré. Avant chaque mise en lutte en juillet 1979, mars et octobre 1980, le troupeau était divisé en trois groupes identiques :

a) brebis traitées avec des éponges vaginales imprégnées de FGA;

b) brebis traitées avec des implants sous-cutanés de Norgestomet;

Une injection intramusculaire de PMSG (500 UI) était effectuée au moment du retrait du progestagène. Dans ces deux groupes, les brebis non fécondées à l'œestrus induit étaient représcntées au mâle le cycle suivant.

c) brebis témoins sans traitement hormonal.

La durée de la période de lutte était de 35 jours chez les brebis témoins.

Le taux de fertilité obtenu après implants de Norgestomet a été plus élevé que pour les autres traitements $(92,2$ vs 83,7 et 84,9 pour respectivement a et $\mathrm{c} ; \mathrm{P}<0.01)$ et au cours de la lutte de juillet $(92,1,78,5$ et 88,0 respectivement pour juillet, mars et octobre).

Un taux de prolificité plus élevé $(P<0,01)$ a été obtenu après utilisation des éponges vaginales (respectivement $166,150,148$ pour $a, b$ et $c$ ) et au cours de la lutte de juillet (169 vs 149 et 147 pour respectivement mars et octobre). 
Par contre, le taux d'apparition des chaleurs n'a été affecté ni par le type de traitement, ni par l'époque de lutte $(100,100,98,2,98,3,99,4$ et 100 pour $a, b, c$ et juillet, mars et octobre respectivement).

Le nombre d'agneaux nés par brebis au cours des deux années a été de $4,15,4,16$ et 3,78 pour les traitements $\mathrm{a}, \mathrm{b}$ et $\mathrm{c}$ respectivement. Ces résultats indiquent que la mise en place d'un système de 3 agnelages en deux ans chez la brebis Pelibuey ne nécessite pas obligatoirement le recours aux techniques hormonales de synchronisation de l'œstrus. fertilité.

Mots clés : brebis à poil, synchronisation des chaleurs, saison, rythme d'agnelage,

Reçu en décembre 1983.

Accepté en août 1984.

\section{References}

Colas G., 1979. Fertility in the ewe after artificial insemination with fresh and frozen semen at the induced oestrus and influence of the photoperiod on the semen quality of the ram. Livest. Prod. Sci., 6, 153-166.

Cognie Y., Mauleon P., 1983. Control of reproduction in the ewe. In : «Sheep Production». Ed. by W. HARESIGN (Butterworths), 381-392.

Fitzhugh H.A., Bradford G.E., 1983. Productivity of Hair sheep and opportunities for improvement in Hair sheep of Western Africa and the Americas. Ed. by H.A. FITzHugH and G.E. BradFord (Westview Press), 12, 23-54.

Mason I.L., 1980. Prolific tropical sheep. FAO Anim. Prod. Health, Rome, FAO, 17.

Thimonier J., CoGNie Y., 1977. Application of control of reproduction of sheep. Proc. Symp. Management of Reproduction in sheep and goats, Madison (Wisc. U.S.A.), July 24-25, 109-118.

Valencia M., Castillo H., Berruecos J.M., 1975. Reproduccion y manejo del borrego Tabasco o Pelibuey. Téc. Pec. Méx., 29, 66. 